\title{
Determination of Retinol, $\alpha$-Tocopherol, Lycopene, and $\beta$-Carotene in Human Plasma Using HPLC with UV-Vis Detection: Application to a Clinical Study
}

\author{
Roman Kand'ár, Pavla Novotná, and Petra Drábková \\ Department of Biological and Biochemical Sciences, Faculty of Chemical Technology, University of Pardubice, \\ 53210 Pardubice, Czech Republic \\ Correspondence should be addressed to Roman Kand’ár; roman.kandar@upce.cz
}

Received 26 June 2012; Revised 13 August 2012; Accepted 29 August 2012

Academic Editor: Gerald Culioli

Copyright (C) 2013 Roman Kand'ár et al. This is an open access article distributed under the Creative Commons Attribution License, which permits unrestricted use, distribution, and reproduction in any medium, provided the original work is properly cited.

\begin{abstract}
A method is described here for the simultaneous determination of retinol, $\alpha$-tocopherol, lycopene, and $\beta$-carotene in human plasma. The effectiveness of various protein precipitants and extraction solvents was tested. After adequate sample preparation, the samples were injected directly into the HPLC system. The separation was realized on an analytical reversed-phase column with a UV-Vis detection. The analytical performance of this method was satisfactory. The intraassay and interassay coefficients of variation were below 10\%. The recoveries were as follows: 97.0\% (CV 2.4\%) for retinol, 94.6\% (CV 1.7\%) for $\alpha$-tocopherol, $91.9 \%$ (CV 3.6\%) for lycopene, and 93.9\% (CV 4.2\%) for $\beta$-carotene. The levels of selected fat-soluble vitamins in plasma of patients with cardiovascular disease were measured and discussed.
\end{abstract}

\section{Introduction}

Fat-soluble vitamins such as $\alpha$-tocopherol, $\beta$-carotene, and lycopene are very important antioxidants [1-3]. Reduced levels of these antioxidants in plasma have been reported to be associated with numerous diseases [3-6]. Association between high plasma levels of fat-soluble antioxidant vitamins and lower risk of atherosclerosis was described in several studies [6]. Vitamin $\mathrm{E}$ is constituted by a group of eight isomers that include both tocopherols and tocotrienols. $\alpha$ Tocopherol is the most biologically active form of vitamin $\mathrm{E}$ [7]. Lycopene is a powerful quencher of singlet oxygen that produced during exposure to ultraviolet light $[8,9]$. $\beta$-Carotene, the main dietary source of Vitamin A, is also a quencher of singlet oxygen $[10,11]$. Numerous methods have been described for the analysis of fat-soluble antioxidant vitamins in various biological matrices. Up to date, several reversed-phase high-performance liquid chromatographic (RP-HPLC) methods using $\mathrm{C}_{18}$ or $\mathrm{C}_{30}$ stationary phase coupled with spectrophotometric, fluorometric, electrochemical, or mass spectrometric detection were developed $[1,2,12-$ 16]. The instability of fat-soluble antioxidant vitamins during sample storage and preparation is the major problem at their measurement. Therefore, sample preparation is essential for accurate analysis of such compounds. While $\alpha$-tocopherol together with retinol are relative stable, $\beta$-carotene and lycopene are easily subject to degradation. Degradation of lycopene and $\beta$-carotene is influenced by temperature, light, and dissolved oxygen [17-19].

The aim of this study was to develop a reliable RP-HPLC method for the measurement of fat-soluble antioxidant vitamins in human plasma and to prevent their degradation during sample preparation.

\section{Experimental}

2.1. Reagents and Chemicals. Retinol, $\alpha$-tocopherol, $\beta$-carotene, lycopene, retinyl acetate, $\alpha$-tocopheryl acetate, $\beta$-apo$8^{\prime}$-carotenal, retinyl palmitate, and 2,6-di-tert-butyl-4methylphenol (butylated hydroxytoluene) were obtained from Sigma (St. Louis, MO, USA). HPLC gradient grade methanol, ethanol, 1-propanol, 2-propanol, acetonitrile, and n-hexane were obtained from Merck (Darmstadt, Germany). All the other chemicals were of analytical grade. 
2.2. Standards Preparation. Stock solutions of retinol $(\approx 20 \mathrm{mg} / \mathrm{L} ; 105 \mu \mathrm{mol} / \mathrm{L}), \alpha$-tocopherol $(\approx 1 \mathrm{~g} / \mathrm{L} ; 2322 \mu \mathrm{mol} /$ $\mathrm{L})$, retinyl acetate $(\approx 20 \mathrm{mg} / \mathrm{L} ; 70 \mu \mathrm{mol} / \mathrm{L})$, and $\alpha$-tocopheryl acetate $(\approx 1 \mathrm{~g} / \mathrm{L} ; 2115 \mu \mathrm{mol} / \mathrm{L})$ were prepared in ethanol. Stock solutions of $\beta$-carotene $(\approx 20 \mathrm{mg} / \mathrm{L} ; 37 \mu \mathrm{mol} / \mathrm{L})$, lycopene $(\approx 20 \mathrm{mg} / \mathrm{L} ; \quad 37 \mu \mathrm{mol} / \mathrm{L})$, retinyl palmitate $(\approx 20 \mathrm{mg} / \mathrm{L}$; $38 \mu \mathrm{mol} / \mathrm{L})$, and $\beta$-apo- $8^{\prime}$-carotenal $(\approx 20 \mathrm{mg} / \mathrm{L} ; 48 \mu \mathrm{mol} / \mathrm{L})$ were prepared in $n$-hexane. All stock solutions were stored at $-20^{\circ} \mathrm{C}$ (maximum of three months). Work solutions of individual vitamins and internal standards were prepared daily and the concentrations were verified spectrophotometrically using molar absorptions:

$$
\begin{aligned}
& \text { concentration of retinol }=\mathrm{A} / 53000(\mathrm{~mol} / \mathrm{L}) \text { at } 325 \mathrm{~nm} \\
& {[20] \text {; }} \\
& \text { concentration of } \alpha \text {-tocopherol }=\mathrm{A} * 248.1(\mu \mathrm{mol} / \mathrm{L}) \\
& \text { at } 292 \mathrm{~nm}[21] \text {; } \\
& \text { concentration of } \beta \text {-carotene }=\mathrm{A} * 4.74(\mu \mathrm{mol} / \mathrm{L}) \text { at } \\
& 450 \mathrm{~nm}[22] \text {; } \\
& \text { concentration of lycopene }=\mathrm{A} * 3.56(\mu \mathrm{mol} / \mathrm{L}) \text { at } \\
& 468 \mathrm{~nm}[22] \text {; } \\
& \text { concentration of retinyl acetate }=\mathrm{A} / 49602(\mathrm{~mol} / \mathrm{L}) \text { at } \\
& 325 \mathrm{~nm}[23] \text {; } \\
& \text { concentration of } \alpha \text {-tocopheryl acetate }=\mathrm{A} / 1891 \\
& (\text { mol/L) at } 290 \mathrm{~nm}[24] \text {. }
\end{aligned}
$$

2.3. Instrumentation. Chromatographic analysis was performed with a liquid chromatograph (Ecom, Prague, Czech Republic) equipped with a LCP 4100 solvent delivery system, an AS 54 autosampler, a LCO 101 column oven, and a LCD 2084 variable wavelength spectrophotometric detector. Data were collected digitally using Clarity chromatography software (DataApex, Prague, Czech Republic). Spectrophotometric analyses were carried out on a Shimadzu (Kyoto, Japan) UV-1700 PharmaSpec spectrophotometer.

2.4. Subjects. A total of 129 patients that diagnosed with nonacute coronary angiography for chest pain (40 women in the age $61 \pm 7$ years and 89 men in the age $59 \pm 7$ years) were included in this study. All patients gave written informed consent to participate in this research study, which was approved by the Hospital Committee on Human Research (Regional Hospital of Pardubice, Czech Republic, protocol 336/2010) according to the Helsinki Declaration.

2.5. Patients' Inclusion and Exclusion Criteria. Criteria for the submission into the study were (1) clinically significant coronary stenosis without subsequent percutaneous coronary intervention (PCI) treatment (coronary stenosis of $>50 \%$ of the left main coronary artery or $>70 \%$ of the epicardial coronary arteries without PCI treatment); (2) stenosis with PCI treatment (stenosis of the same grade with subsequent PCI treatment); (3) patients without any stenosis (symptoms imitating coronary artery disease with normal angiographic finding and no stenosis). All participants underwent angiography and completed a questionnaire. Patients who had any serious health complications and patients with increased high-sensitivity C-reactive protein levels (>10 mg/L) were excluded. None of the studied subjects exhibited renal, hepatic, gastrointestinal, pulmonary, or oncological diseases.

2.6. Blood Samples Collection. Venous blood samples were obtained under standard conditions, from 7 to 8 a.m. after fasting for at least 12 hours the day after coronarographic examination. Blood was collected into tubes with EDTA (the Vacuette Detection Tube, No. 454246, Greiner Labortechnik Co., Kremsmünster, Austria) that covered with an aluminum foil to minimize exposure of blood samples to daylight. Plasma was separated from blood cells by centrifugation $\left(1700 \times \mathrm{g}, 15 \mathrm{~min}, 8^{\circ} \mathrm{C}\right)$ and immediately stored at $-80^{\circ} \mathrm{C}$ in 1.5-mL amber polypropylene tubes.

2.7. Sample Preparation. Retinyl acetate and $\alpha$-tocopheryl acetate were used as internal standards. They are not present in human plasma and their chromatographic properties are quite similar. On the other hand, retinyl palmitate and $\beta$-apo$8^{\prime}$-carotenal were detected in most of the samples.

All procedures were performed in a darkened room.

For the analysis of blood plasma, $10 \mu \mathrm{L}$ of the internal standard of retinyl acetate solution in ethanol $(\approx 40 \mu \mathrm{mol} / \mathrm{L}$; $13 \mu \mathrm{g} / \mathrm{mL}$ ) and $10 \mu \mathrm{L}$ of the internal standard $\alpha$-tocopheryl acetate solution in ethanol $(\approx 2 \mathrm{mmol} / \mathrm{L} ; 945 \mu \mathrm{g} / \mathrm{mL})$ were pipetted into a well-capped $1.5-\mathrm{mL}$ amber polypropylene tube. $200 \mu \mathrm{L}$ of plasma were added and the content mixed vigorously on a vortex mixer for $10 \mathrm{~min} .200 \mu \mathrm{L}$ of cold ethanol were added and the solution was vortexed for $60 \mathrm{~s}$. $500 \mu \mathrm{L}$ of cold $\mathrm{n}$-hexane containing butylated hydroxytoluene $(1 \mathrm{~g} / \mathrm{L})$ were then added, the solution was vortexed for $5 \mathrm{~min}$, and centrifuged $\left(22000 \times \mathrm{g}, 5 \mathrm{~min}, 4^{\circ} \mathrm{C}\right)$. The upper hexane layer was transferred into $5-\mathrm{mL}$ amber glass tubes. The hexane extraction process was repeated two times. Combined hexane extracts were evaporated to dryness, under nitrogen, at $4^{\circ} \mathrm{C}$ (Linde Gas, Prague, Czech Republic). The dried residue was resuspended in $200 \mu \mathrm{L}$ of cold ethanol and vortexed for $60 \mathrm{~s}$. The sample was then filtered through a nylon filter (pore size $0.20 \mu \mathrm{m}, 4 \mathrm{~mm}$ diameter, Supelco, Bellefonte, PA, USA), transferred into $0.2-\mathrm{mL}$ cramped amber vial, and purged with pure nitrogen for $10 \mathrm{~s}$.

The stock solutions of fat-soluble vitamins were diluted with ethanol (retinol, $\alpha$-tocopherol) or n-hexane (lycopene, $\beta$-carotene) to give a series of mixed working standards. To $200 \mu \mathrm{L}$ of mixed solution of standards, $10 \mu \mathrm{L}$ of the internal standard of retinyl acetate solution in ethanol $(\approx 40 \mu \mathrm{mol} / \mathrm{L}$; $13 \mu \mathrm{g} / \mathrm{mL}), 10 \mu \mathrm{L}$ of the internal standard $\alpha$-tocopheryl acetate solution in ethanol $(\approx 2 \mathrm{mmol} / \mathrm{L} ; 945 \mu \mathrm{g} / \mathrm{mL}), 200 \mu \mathrm{L}$ of deionized water, and $500 \mu \mathrm{L}$ of cold n-hexane containing butylated hydroxytoluene $(1 \mathrm{~g} / \mathrm{L})$ were carefully added. Prepared standards were subjected to the same procedure as described above for plasma samples.

For recovery experiments, $10 \mu \mathrm{L}$ of mixed solution of individual vitamins at different concentrations was added to $190 \mu \mathrm{L}$ of plasma. The next steps were the same as for plasma sample preparation. 
2.8. Chromatographic Analysis. The chromatographic analysis of selected fat-soluble vitamins was accomplished using an isocratic elution on a Discovery $\mathrm{HS} \mathrm{C}_{18}, 150 \times 4 \mathrm{~mm}$ i.d., $5 \mu \mathrm{m}$ analytical column that fitted with a Discovery $\mathrm{C}_{18}$, $20 \times 4 \mathrm{~mm}$ i.d., $5 \mu \mathrm{m}$ guard column (Supelco, Bellefonte, PA, USA) at $40^{\circ} \mathrm{C}$. The mobile phase was a mixture of methanol and ethanol $(75: 25, \mathrm{v} / \mathrm{v})$. The flow rate was kept constant at $0.8 \mathrm{~mL} / \mathrm{min}$. Optimum response of $\alpha$-tocopherol and $\alpha$-tocopheryl acetate was observed when wavelength was set at $292 \mathrm{~nm}$, while retinol together with retinyl acetate were monitored at $325 \mathrm{~nm}, \beta$-carotene at $450 \mathrm{~nm}$, and lycopene at $468 \mathrm{~nm}$. The amount of individual vitamins was quantified from the corresponding peak area ratio of vita$\mathrm{min} /$ internal standard $(\alpha$-tocopherol/ $\alpha$-tocopheryl acetate; retinol, lycopene, and $\beta$-carotene/retinyl acetate) using Clarity chromatography software (DataApex). The concentration of each analyte in the samples was determined from its calibration curve.

2.9. Statistical Analysis. The data are presented as mean \pm S.D. Differences between studied groups were analyzed using the Student's $t$-test. The correlation analysis was carried out using Spearman Rank Order Correlation, and regression analysis was carried out using the least squares method (software QCexpert, Trilobyte, Pardubice, Czech Republic). A $P<0.05$ value was considered statistically significant.

\section{Results and Discussion}

3.1. Sample Preparation, Stability. Sample preparation is essential for accurate analysis. The stability of selected fat-soluble vitamins in human plasma during the sample treatment was investigated. Several protein precipitants were tested. Protein precipitant of the different temperature (methanol, acetonitrile, ethanol, 1-propanol, and 2propanol) was carefully added to plasma. Then n-hexane containing or not an antioxidant (butylated hydroxytoluene) was carefully added. Fat-soluble vitamins and internal standards in plasma samples were found to be stable at $4^{\circ} \mathrm{C}$ for at least $8 \mathrm{~h}$ under these conditions: a protein precipitation with ethanol, cooled to $-20^{\circ} \mathrm{C}$; extraction with $\mathrm{n}$-hexane containing butylated hydroxytoluene, cooled to $-20^{\circ} \mathrm{C}$; centrifugation at $4^{\circ} \mathrm{C}$; evaporation to dryness, under pure nitrogen, at $4^{\circ} \mathrm{C}$; resuspension of a residue in ethanol, cooled to $-20^{\circ} \mathrm{C}$. It is very important that extracts were to be dried as quickly as possible. Fat-soluble vitamins, especially lycopene, are not stable in n-hexane. Fat-soluble vitamins in human plasma samples that stored at $-80^{\circ} \mathrm{C}$ are stable for at least one year. It is necessary that all procedures were to be performed in a darkened room.

\subsection{High-Performance Liquid Chromatographic Assay of} Fat-Soluble Vitamins. Fat-soluble vitamins were separated on a reversed-phase column using an isocratic system of methanol and ethanol. The mobile phase was optimized in order to obtain the best separation of the analytes in the shortest time. Standard solutions of fat-soluble vitamins and internal standards as well as pooled plasma samples

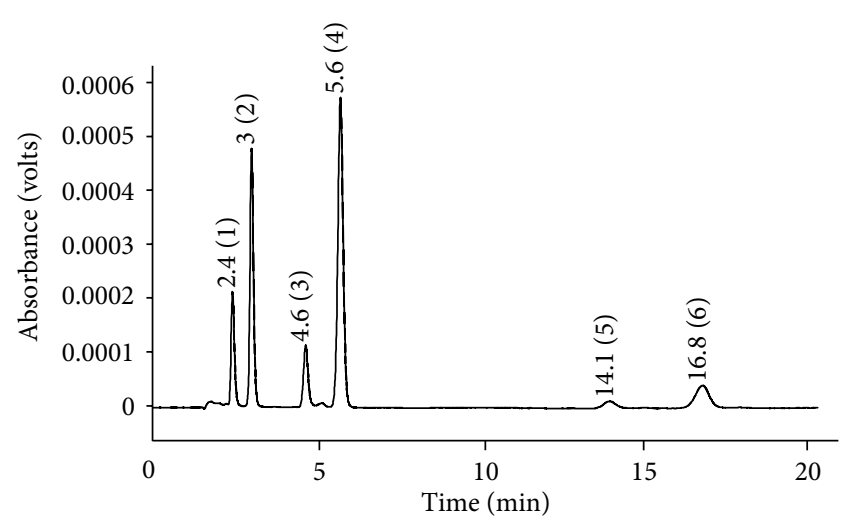

FIGURE 1: An HPLC chromatogram of retinol $(1.00 \mu \mathrm{mol} / \mathrm{L}$; $0.29 \mu \mathrm{g} / \mathrm{mL}), \alpha$-tocopherol $(15.0 \mu \mathrm{mol} / \mathrm{L} ; 6.46 \mu \mathrm{g} / \mathrm{mL})$, lycopene $(0.020 \mu \mathrm{mol} / \mathrm{L} ; \quad 0.011 \mu \mathrm{g} / \mathrm{mL})$, and $\beta$-carotene $(0.100 \mu \mathrm{mol} / \mathrm{L}$; $0.054 \mu \mathrm{g} / \mathrm{mL}$ ) in standard solution. Peaks: (1) retinol, (2) retinyl acetate, (3) $\alpha$-tocopherol, (4) $\alpha$-tocopheryl acetate, (5) lycopene, and (6) $\beta$-carotene. HPLC conditions: an isocratic elution (mobile phase: methanol-ethanol, $75: 25, \mathrm{v} / \mathrm{v}$ ); the stationary phase was an analytical column Discovery $\mathrm{HS} \mathrm{C}_{18}, 150 \times 4 \mathrm{~mm}$ i.d., $5 \mu \mathrm{m}$ fitted with a Discovery $\mathrm{C}_{18}, 20 \times 4 \mathrm{~mm}$ i.d., $5 \mu \mathrm{m}$ guard column; the flow rate was kept constant at $0.8 \mathrm{~mL} / \mathrm{min}$, separation ran at $40^{\circ} \mathrm{C}$. Retinol together with retinyl acetate was monitored at $325 \mathrm{~nm}, \alpha$ tocopherol together with $\alpha$-tocopheryl acetate was monitored at $292 \mathrm{~nm}$, lycopene was monitored at $468 \mathrm{~nm}$, and $\beta$-carotene was monitored at $450 \mathrm{~nm}$.

were used for studying the mobile phase composition. Several eluents (mixtures of organic solvents such as acetonitrile, methanol, ethanol, 1-propanol, 2-propanol, and n-hexane) and several gradients were assessed. The best results were obtained for the conditions that described in "Chromatographic Analysis." Column temperature was changed from 25 to $45^{\circ} \mathrm{C}$. Optimal temperature interval was from 40 to $45^{\circ} \mathrm{C}$. The criteria were resolution, stability of the absorbance, and analysis duration. According to our results, we can conclude that the presented method is highly robust. HPLC chromatograms of fat-soluble vitamins in standard solution and human plasma are shown in Figures 1 and 2. The precision of fat-soluble vitamin analysis in plasma samples is shown in Table 1. To determine the same-day precision, the plasma samples were analyzed ten times in the same day under the same conditions. Similarly, data on the betweenday precision were obtained using the same plasma samples, analyzed on ten different days. The coefficients of variation were below $10 \%$. The spike recoveries ranged between 93.8 and $99.4 \%$ for retinol, $92.2-95.9 \%$ for $\alpha$-tocopherol, $87.7-95.8 \%$ for lycopene, and $88.6-98.8 \%$ for $\beta$-carotene (Figure 3). Calibration curves (9-point for determining analytical parameters and 7-point for routine analysis) were linear over the whole tested range (Figure 4). The calibration curve parameters obtained as an average from ten standard curves are shown in Table 2. The lowest concentration that could be quantified with acceptable accuracy and precision was $0.1 \mu \mathrm{mol} / \mathrm{L}(2.2 \mathrm{pmol} /$ inject $)$ for retinol, $2.1 \mu \mathrm{mol} / \mathrm{L}$ (46.2 pmol/inject) for $\alpha$-tocopherol, $\quad 0.020 \mu \mathrm{mol} / \mathrm{L}$ $(0.44 \mathrm{pmol} /$ inject $)$ for lycopene, and $0.021 \mu \mathrm{mol} / \mathrm{L}$ 


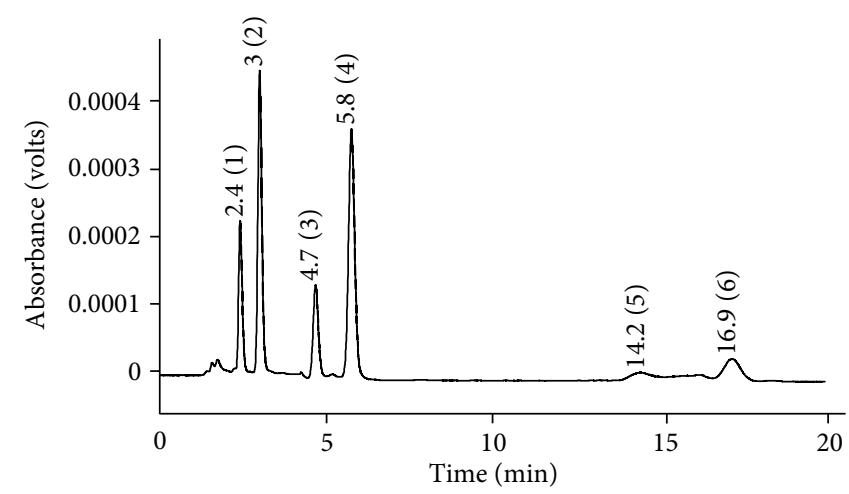

Figure 2: An HPLC chromatogram of retinol (1.14 $\mu \mathrm{mol} / \mathrm{L} ; 0.33 \mu \mathrm{g} / \mathrm{mL}), \alpha$-tocopherol $(27.3 \mu \mathrm{mol} / \mathrm{L} ; 11.76 \mu \mathrm{g} / \mathrm{mL})$, lycopene $(0.021 \mu \mathrm{mol} / \mathrm{L}$; $0.011 \mu \mathrm{g} / \mathrm{mL})$, and $\beta$-carotene $(0.073 \mu \mathrm{mol} / \mathrm{L} ; 0.039 \mu \mathrm{g} / \mathrm{mL})$ in human plasma. Peaks: (1) retinol, (2) retinyl acetate, (3) $\alpha$-tocopherol, (4) $\alpha$ tocopheryl acetate, (5) lycopene, and (6) $\beta$-carotene. HPLC conditions: see Figure 1.

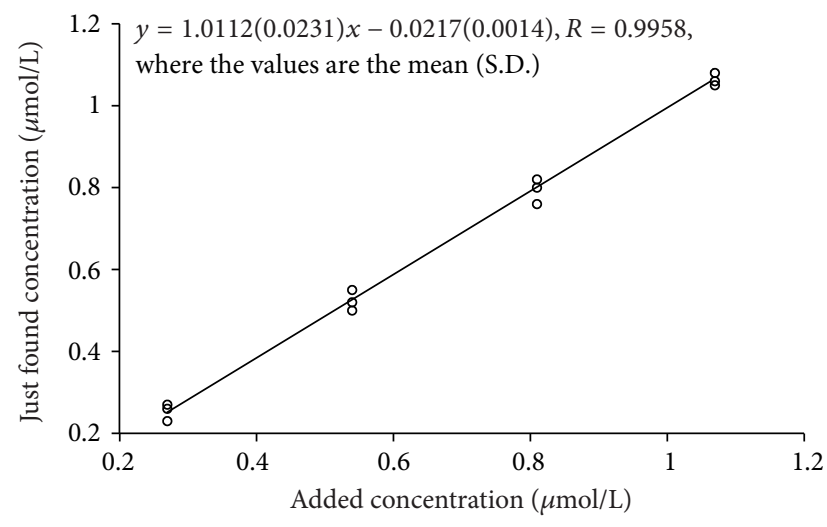

(a)

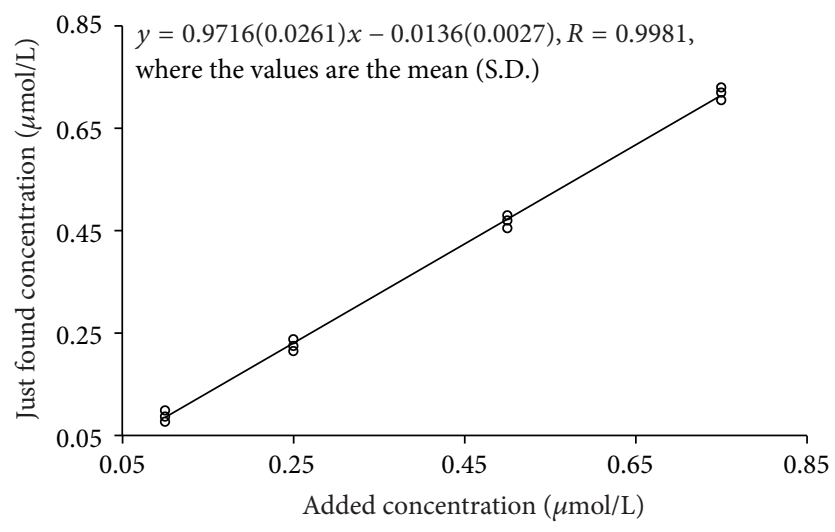

(c)

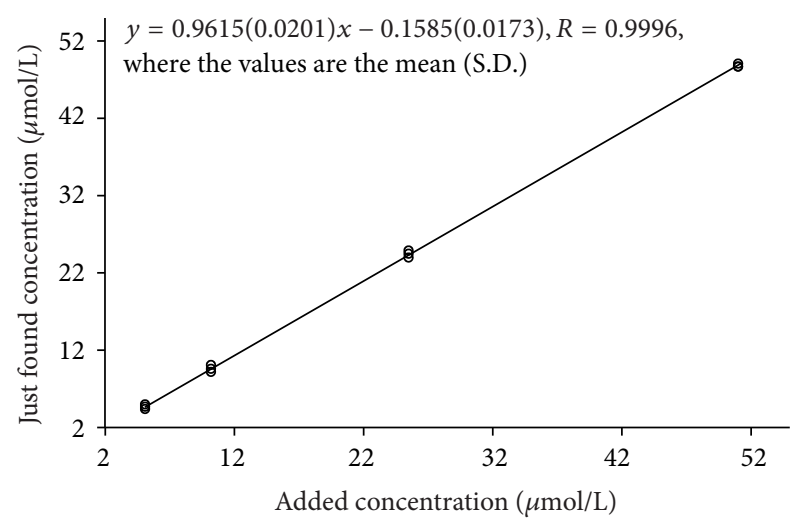

(b)

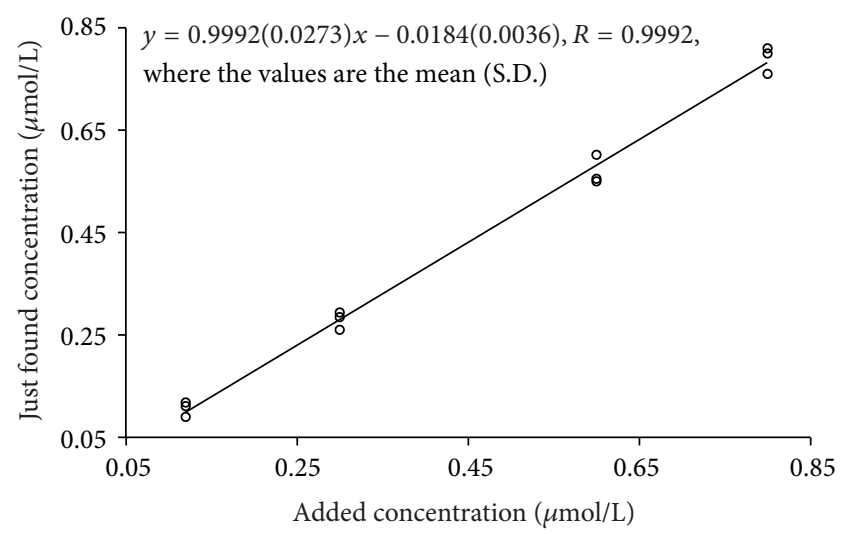

(d)

FIGURE 3: Recovery experiment: retinol (a), $\alpha$-tocopherol (b), lycopene (c), and $\beta$-carotene (d). Values of triplicate assays are recorded. Slopes correspond to the mean recovery $97.0 \%($ S.D. $=2.4 \%$ ) for retinol, $94.6 \%$ (S.D. $=1.7 \%$ ) for $\alpha$-tocopherol, $91.9 \%$ (S.D. 3.6\%) for lycopene, and 93.9\% (S.D. $=4.2 \%)$ for $\beta$-carotene.

$(0.46 \mathrm{pmol} /$ inject $)$ for $\beta$-carotene. Furthermore, the limits of detection for retinol, $\alpha$-tocopherol, lycopene, and $\beta$-carotene, defined as a signal-to-noise $(\mathrm{S} / \mathrm{N})$ ratio of $3: 1$, were $0.03 \mu \mathrm{mol} / \mathrm{L} \quad(0.7 \mathrm{pmol} /$ inject $), 0.63 \mu \mathrm{mol} / \mathrm{L}$ (13.9 pmol/inject), $\quad 0.006 \mu \mathrm{mol} / \mathrm{L} \quad(0.13 \mathrm{pmol} /$ inject $)$, and $0.006 \mu \mathrm{mol} / \mathrm{L}$ ( $0.13 \mathrm{pmol} /$ inject $)$, respectively.
3.3. Determination of Selected Fat-Soluble Vitamins in Human Plasma of Patients with Cardiovascular Diseases. The role of retinol, $\alpha$-tocopherol, and carotenoids in both physiological and pathological processes has been widely discussed. Many of the biological actions of these fat-soluble vitamins have been attributed to their antioxidant properties. Several 


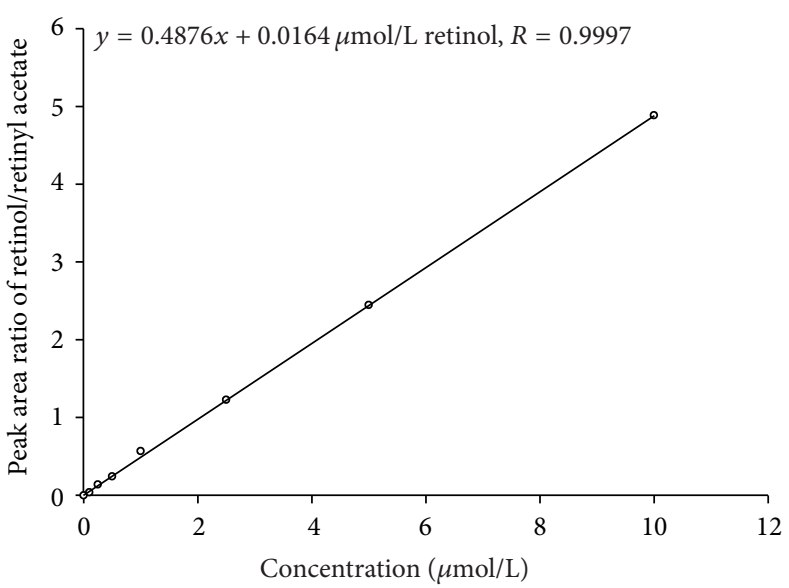

(a)

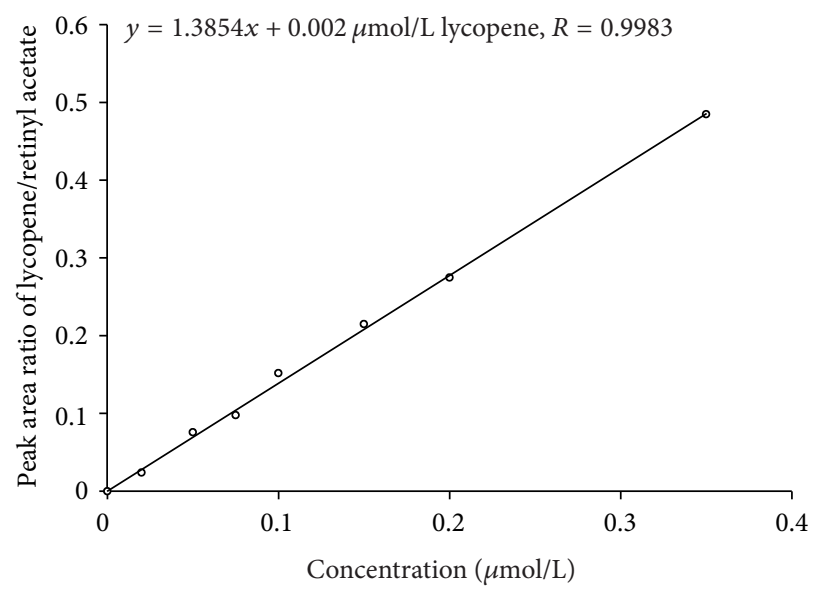

(c)

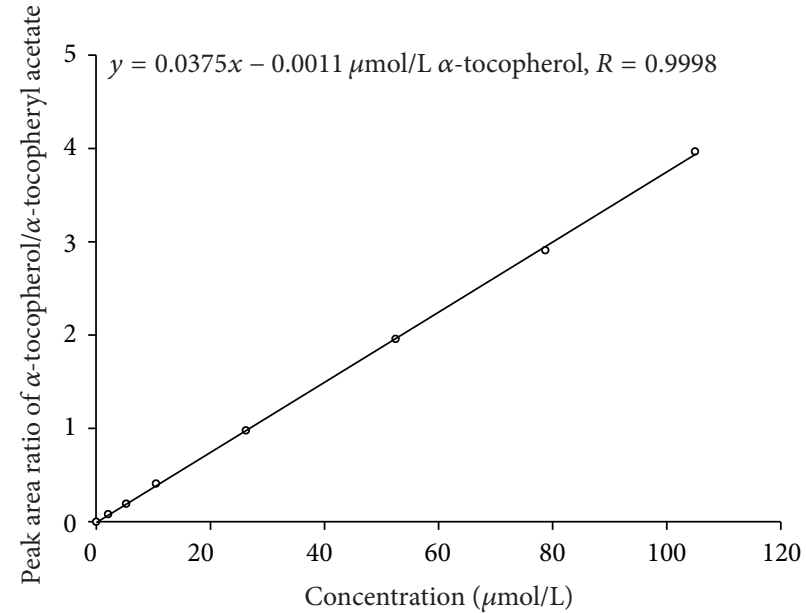

(b)

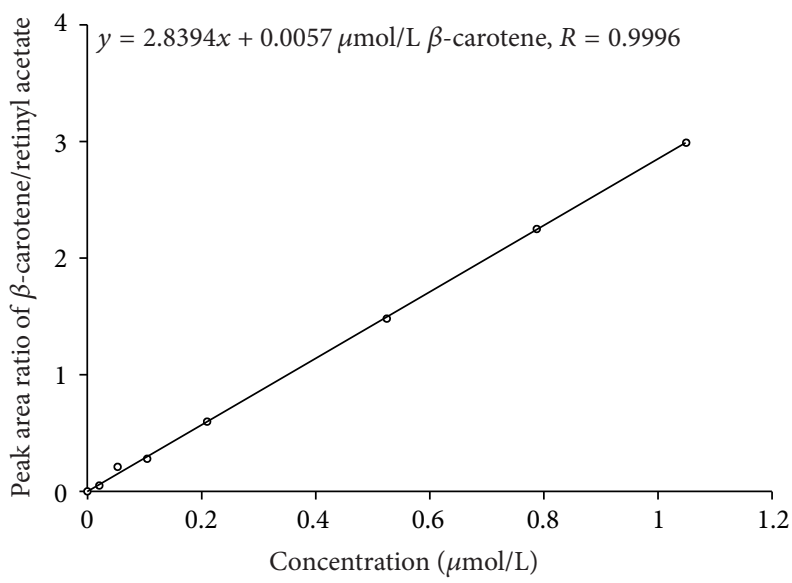

(d)

FIgURE 4: Typical calibration curves for HPLC quantification of retinol (a), $\alpha$-tocopherol (b), lycopene (c), and $\beta$-carotene (d).

TABLE 1: Precision of retinol, $\alpha$-tocopherol, lycopene, and $\beta$-carotene in human plasma.

\begin{tabular}{|c|c|c|c|c|c|c|c|c|}
\hline & $\begin{array}{c}\text { Retinol } \\
\text { mean } \pm \text { S.D. } \\
\mu \mathrm{mol} / \mathrm{L}\end{array}$ & $\mathrm{CV}, \%$ & $\begin{array}{c}\alpha \text {-Tocopherol } \\
\text { mean } \pm \text { S.D., } \\
\mu \mathrm{mol} / \mathrm{L}\end{array}$ & $\mathrm{CV}, \%$ & $\begin{array}{c}\text { Lycopene } \\
\text { mean } \pm \text { S.D., } \\
\mu \mathrm{mol} / \mathrm{L}\end{array}$ & $\mathrm{CV}, \%$ & $\begin{array}{c}\beta \text {-Carotene } \\
\text { mean } \pm \text { S.D. } \\
\mu \mathrm{mol} / \mathrm{L}\end{array}$ & $\mathrm{CV}, \%$ \\
\hline \multicolumn{9}{|c|}{ (A) Precision (within day) } \\
\hline 10 & $1.27 \pm 0.07$ & 5.5 & $22.1 \pm 0.69$ & 3.1 & $0.069 \pm 0.005$ & 7.2 & $0.270 \pm 0.018$ & 6.7 \\
\hline 10 & $3.02 \pm 0.15$ & 5.0 & $28.2 \pm 0.73$ & 2.6 & $0.097 \pm 0.006$ & 6.2 & $0.615 \pm 0.029$ & 4.7 \\
\hline \multicolumn{9}{|c|}{ (B) Precision (between day) } \\
\hline 10 & $3.05 \pm 0.21$ & 6.9 & $28.8 \pm 1.21$ & 4.2 & $0.099 \pm 0.009$ & 9.1 & $0.611 \pm 0.048$ & 7.9 \\
\hline
\end{tabular}

TABLE 2: Average parameters of 10 calibration curves for the HPLC method.

\begin{tabular}{llccc}
\hline Standard & Regression equation & $\begin{array}{c}\text { Mean slope } \\
95 \% \text { confidence interval }\end{array}$ & $\begin{array}{c}\text { Intercept }(\mu \mathrm{mol} / \mathrm{L})^{2} \\
\text { 95\% confidence interval }\end{array}$ & Correlation coefficient \\
\hline Retinol $^{1}$ & $y=0.4876 x+0.0164$ & $0.4876(0.4528-0.5221)$ & $-0.03(-0.06-0.01)$ & 0.9997 \\
${\text { - } \text { Tocopherol }^{1}}^{\text {Lycopene }^{1}}$ & $y=0.0375 x-0.0011$ & $0.0375(0.0342-0.0402)$ & $0.03(-0.21-0.26)$ & 0.9998 \\
$\beta$-Carotene & $y=1.3854 x+0.0020$ & $1.3854(1.2731-1.4001)$ & $-0.001(-0.005-0.003)$ & 0.9983 \\
\hline
\end{tabular}

${ }^{1}$ Nine-point for the determination of analytical parameters and seven-point for routine analysis. ${ }^{2}$ The $x$-intercept (in $\mu$ mol/L) is the point at which the line crosses the $x$-axis (where the $y$ value equals 0 ). 
TABLE 3: Comparison of levels of selected fat-soluble antioxidant vitamins between the patients and a control group.

\begin{tabular}{|c|c|c|c|c|c|}
\hline & $\begin{array}{c}\text { PCI } \\
(1 ; n=45)\end{array}$ & $\begin{array}{c}P \\
(2 ; n=37)\end{array}$ & $\begin{array}{c}N \\
(3 ; n=47)\end{array}$ & 1 versus 3 & 2 versus 3 \\
\hline Age (years) & $59 \pm 5$ & $61 \pm 6$ & $57 \pm 6$ & - & - \\
\hline Female/male & $9 / 36$ & $6 / 31$ & $25 / 22$ & - & - \\
\hline $\begin{array}{l}\text { Retinol } \\
(\mu \mathrm{mol} / \mathrm{L} ; \mu \mathrm{g} / \mathrm{mL})\end{array}$ & $\begin{array}{l}1.21(0.49) \\
0.35(0.14)\end{array}$ & $\begin{array}{l}1.26(0.33) ; \\
0.36(0.09)\end{array}$ & $\begin{array}{l}1.14(0.32) ; \\
0.33(0.09)\end{array}$ & - & - \\
\hline $\begin{array}{l}\alpha \text {-Tocopherol } \\
(\mu \mathrm{mol} / \mathrm{L} ; \mu \mathrm{g} / \mathrm{mL})\end{array}$ & $\begin{array}{l}22.1(4.4) \\
9.52(1.90)\end{array}$ & $\begin{array}{c}23.6(9.7) \\
10.16(4.18)\end{array}$ & $\begin{array}{c}23.7(5.7) ; \\
10.21(2.46)\end{array}$ & - & - \\
\hline $\begin{array}{l}\text { Lycopene } \\
(\mu \mathrm{mol} / \mathrm{L} ; \mu \mathrm{g} / \mathrm{mL})\end{array}$ & $\begin{array}{c}0.025(0.010) \\
0.013(0.005)\end{array}$ & $\begin{array}{c}0.038(0.023) \\
0.020(0.012)\end{array}$ & $\begin{array}{l}0.039(0.009) ; \\
0.021(0.005)\end{array}$ & * & - \\
\hline $\begin{array}{l}\beta \text {-Carotene } \\
(\mu \mathrm{mol} / \mathrm{L} ; \mu \mathrm{g} / \mathrm{mL})\end{array}$ & $\begin{array}{l}0.095(0.117) \\
0.051(0.063)\end{array}$ & $\begin{array}{l}0.106(0.120) ; \\
0.057(0.064)\end{array}$ & $\begin{array}{l}0.139(0.098) ; \\
0.075(0.053)\end{array}$ & $* * *$ & $* *$ \\
\hline
\end{tabular}

Results are expressed as the mean value with the estimated standard deviation (S.D.), the statistical significance of a difference: ${ }^{*} P<0.05$; ${ }^{* *} P<0.01 ;{ }^{* * *} P<$ 0.001 (Student's $t$-test).

PCI: patients with stenosis and with subsequent percutaneous coronary intervention.

$P$ : patients with stenosis without subsequent percutaneous coronary intervention.

$N$ : patients without any stenosis.

studies showed an inverse association between fat-soluble antioxidant vitamins in plasma levels and atherosclerotic progression in arteries $[25,26]$. The patients with cardiovascular disease were divided into 3 groups according to the results of angiographic examination. Blood samples were collected the day after coronarographic examination. Mean values $( \pm$ S.D.) of selected fat-soluble vitamins are shown in Table 3. In patients with stenosis and with subsequent percutaneous coronary intervention (PCI), significantly more in men, lower levels of $\beta$-carotene and lycopene were detected. In patients with stenosis without subsequent percutaneous coronary intervention $(\mathrm{P})$, significantly more in men, lower levels of $\beta$-carotene were detected. Now our results revealed a significant correlation of coronary artery disease occurrence and low carotenoids levels. Beside antioxidant properties, carotenoids have other important functions such as protection of DNA against peroxidation, enhancement of gap junctional communication, immunomodulation, and tumorsuppressive activity. However, the exact mechanisms leading to the beneficial effects in atherosclerosis are still under debate. Levels of $\beta$-carotene and lycopene were markedly below the recommended plasma concentrations in all groups. Women generally have higher concentrations of fat-soluble antioxidant vitamins, especially carotenoids. Several factors influence plasma concentrations of such compounds: sex, age, dietary intake, smoking and drinking habits, and seasonality [27-29]. Significant correlation between retinol concentration and age $(R=-0.480, P=0.0098)$ in patients without any stenosis $(N)$ and between lycopene concentration and age $(R=-0743, P=0.0108)$ in $P$ patients was observed.

\section{Conclusions}

A reliable, selective, and sensitive HPLC method with spectrophotometric detection for the determination of retinol, $\alpha$ tocopherol, lycopene, and $\beta$-carotene in human plasma was developed. Proper sample preparation preventing fat-soluble antioxidant vitamins degradation is required to achieve accurate analyses. The crucial points are sample collection, protein precipitation, and liquid-liquid extraction. The best results were obtained under these conditions:

tubes for blood sampling containing EDTA and covered with aluminum foil;

fast freezing of plasma samples $\left(-80^{\circ} \mathrm{C}\right)$;

cold ethanol $\left(-20^{\circ} \mathrm{C}\right)$ as a protein precipitant;

extraction with cold $n$-hexane $\left(-20^{\circ} \mathrm{C}\right)$ containing an antioxidant (butylated hydroxytoluene);

evaporation to dryness, under pure nitrogen (purity 4.6 and more), at $4^{\circ} \mathrm{C}$;

resuspension of the obtained residue in cold ethanol $\left(-20^{\circ} \mathrm{C}\right)$;

transfer of the prepared samples into $0.2-\mathrm{mL}$ cramped amber vials and treatment with pure nitrogen for $10 \mathrm{~s}$.

\section{Acknowledgment}

This work was supported by Grants SGFChT07/2012 and MSMT 0021627502 from the Czech Ministry of Education.

\section{References}

[1] F. Xu, Q. P. Yuan, and H. R. Dong, "Determination of lycopene and $\beta$-carotene by high-performance liquid chromatography using sudan I as internal standard," Journal of Chromatography $B$, vol. 838, no. 1, pp. 44-49, 2006.

[2] B. L. Lee and C. N. Ong, "Comprehensive high-performance liquid chromatographic method for the measurements of lipophilic antioxidants in human plasma," Journal of Chromatography A, vol. 1216, no. 15, pp. 3131-3137, 2009.

[3] D. C. Schwenke, "Does lack of tocopherols and tocotrienols put women at increased risk of breast cancer?" Journal of Nutritional Biochemistry, vol. 13, no. 1, pp. 2-20, 2002.

[4] C. Persson, S. Sasazuki, M. Inoue et al., "Plasma levels of carotenoids, retinol and tocopherol and the risk of gastric 
cancer in Japan: a nested case-control study,' Carcinogenesis, vol. 29, no. 5, pp. 1042-1048, 2008.

[5] L. Wang, J. M. Gaziano, E. P. Norkus, J. E. Buring, and H. D. Sesso, "Associations of plasma carotenoids with risk factors and biomarkers related to cardiovascular disease in middle-aged and older women," American Journal of Clinical Nutrition, vol. 88, no. 3, pp. 747-754, 2008.

[6] R. Stocker and J. F. Keaney Jr., "Role of oxidative modifications in atherosclerosis," Physiological Reviews, vol. 84, no. 4, pp. 1381-1478, 2004.

[7] Y. Yoshida, E. Niki, and N. Noguchi, "Comparative study on the action of tocopherols and tocotrienols as antioxidant: chemical and physical effects," Chemistry and Physics of Lipids, vol. 123, no. 1, pp. 63-75, 2003.

[8] M. Kelkel, M. Schumacher, M. Dicato, and M. Diederich, "Antioxidant and anti-proliferative properties of lycopene," Free Radical Research, vol. 45, no. 8, pp. 925-940, 2011.

[9] K. T. Tsen, S. W. D. Tsen, and J. G. Kiang, "Lycopene is more potent than beta carotene in the neutralization of singlet oxygen: role of energy transfer probed by ultrafast raman spectroscopy," Journal of Biomedical Optics, vol. 11, no. 6, Article ID 064025, 2006.

[10] C. H. Chen, R. M. Han, R. Liang et al., "Direct observation of the $\beta$-carotene reaction with hydroxyl radical," Journal of Physical Chemistry B, vol. 115, no. 9, pp. 2082-2089, 2011.

[11] K. Fukuzawa, Y. Inokami, A. Tokumura, J. Terao, and A. Suzuki, "Singlet oxygen scavenging by alpha-tocopherol and beta-carotene: kinetic studies in phospholipid membranes and ethanol solution," BioFactors, vol. 7, no. 1-2, pp. 31-40, 1998.

[12] R. Andreoli, P. Manini, D. Poli, E. Bergamaschi, A. Mutti, and W. M. A. Niessen, "Development of a simplified method for the simultaneous determination of retinol, $\alpha$-tocopherol, and $\beta$-carotene in serum by liquid chromatography_tandem mass spectrometry with atmospheric pressure chemical ionization," Analytical and Bioanalytical Chemistry, vol. 378, no. 4, pp. 987-994, 2004.

[13] W. A. Maccrehan and E. Schönberger, "Determination of retinol, alpha-tocopherol, and beta-carotene in serum by liquid chromatography with absorbance and electrochemical detection," Clinical Chemistry, vol. 33, no. 9, pp. 1585-1592, 1987.

[14] K. Nakagawa, T. Kiko, K. Hatade et al., "Development of a high-performance liquid chromatography-based assay for carotenoids in human red blood cells: application to clinical studies," Analytical Biochemistry, vol. 381, no. 1, pp. 129-134, 2008.

[15] D. Thibeault, H. Su, E. MacNamara, and H. M. Schipper, "Isocratic rapid liquid chromatographic method for simultaneous determination of carotenoids, retinol, and tocopherols in human serum," Journal of Chromatography B, vol. 877, no. 1112, pp. 1077-1083, 2009.

[16] H. Ortega, J. L. Coperías, P. Castilla, D. Gómez-Coronado, and M. A. Lasunción, "Liquid chromatographic method for the simultaneous determination of different lipid-soluble antioxidants in human plasma and low-density lipoproteins," Journal of Chromatography B, vol. 803, no. 2, pp. 249-255, 2004.

[17] J. Giasson, M. Hernandez, and Y. Chen, "Stability of serum carotene at various light and temperature conditions," Archives of Pathology and Laboratory Medicine, vol. 135, no. 12, pp. 1529-1530, 2011.

[18] J. Brown Thomas, D. L. Duewer, M. C. Kline, and K. E. Sharpless, "The stability of retinol, $\alpha$-tocopherol, trans-lycopene, and trans- $\beta$-carotene in liquid-frozen and lyophilized serum," Clinica Chimica Acta, vol. 276, no. 1, pp. 75-87, 1998.

[19] G. Scita, "Stability of $\beta$-carotene under different laboratory conditions," Methods in Enzymology, vol. 213, pp. 175-185, 1992.

[20] A. L. Sowell, D. L. Huff, P. R. Yeager, S. P. Caudill, and E. W. Gunter, "Retinol, $\alpha$-tocopherol, lutein/zeaxanthin, $\beta$ cryptoxanthin, lycopene, $\alpha$-carotene, trans- $\beta$-carotene, and four retinyl esters in serum determined simultaneously by reversed-phase HPLC with multiwavelength detection," Clinical Chemistry, vol. 40, no. 3, pp. 411-416, 1994.

[21] B. Finckh, A. Kontush, J. Commentz, C. Hübner, M. Burdelski, and A. Kohlschütter, "Monitoring of ubiquinol-10, ubiquinone10 , carotenoids, and tocopherols in neonatal plasma microsamples using high-performance liquid chromatography with coulometric electrochemical detection," Analytical Biochemistry, vol. 232, no. 2, pp. 210-216, 1995.

[22] T. L. Bierer, N. R. Merchen, and J. W. Erdman Jr., "Comparative absorption and transport of five common carotenoids in preruminant calves," Journal of Nutrition, vol. 125, no. 6, pp. 1569-1577, 1995.

[23] M. A. Abahusain, J. Wright, J. W. T. Dickerson, M. A. El-Hazmi, and H. Y. Aboul Enein, "Determination of retinol, $\alpha$ tocopherol, $\alpha$ - and $\beta$-carotene by direct extraction of human serum using high performance liquid chromatography," Biomedical Chromatography, vol. 12, no. 2, pp. 89-93, 1998.

[24] D. Talwar, T. K. Ha, J. Cooney, C. Brownlee, and D. S. O’Reilly, “A routine method for the simultaneous measurement of retinol, $\alpha$-tocopherol and five carotenoids in human plasma by reverse phase HPLC," Clinica Chimica Acta, vol. 270, no. 2, pp. 85-100, 1998.

[25] M. C. Polidori, D. Praticó, B. Parente et al., "Elevated lipid peroxidation biomarkers and low antioxidant status in atherosclerotic patients with increased carotid or iliofemoral intima media thickness," Journal of Investigative Medicine, vol. 55, no. 4, pp. 163-167, 2007.

[26] G. Riccioni, N. D’Orazio, N. Palumbo et al., "Relationship between plasma antioxidant concentrations and carotid intimamedia thickness: the asymptomatic carotid atherosclerotic disease in manfredonia study," European Journal of Cardiovascular Prevention and Rehabilitation, vol. 16, no. 3, pp. 351-357, 2009.

[27] A. L. Garcia, C. Koebnick, P. C. Dagnelie et al., "Long-term strict raw food diet is associated with favourable plasma $\beta$ carotene and low plasma lycopene concentrations in germans," British Journal of Nutrition, vol. 99, no. 6, pp. 1293-1300, 2008.

[28] D. K. Talwar, M. K. Azharuddin, C. Williamson, Y. P. Teoh, D. C. McMillan, and D. S. J. O'Reilly, "Biological variation of vitamins in blood of healthy individuals," Clinical Chemistry, vol. 51, no. 11, pp. 2145-2150, 2005.

[29] B. Olmedilla, F. Granado, S. Southon et al., "Serum concentrations of carotenoids and vitamins A, E, and C in control subjects from five european countries," British Journal of Nutrition, vol. 85 , no. 2, pp. 227-238, 2001. 

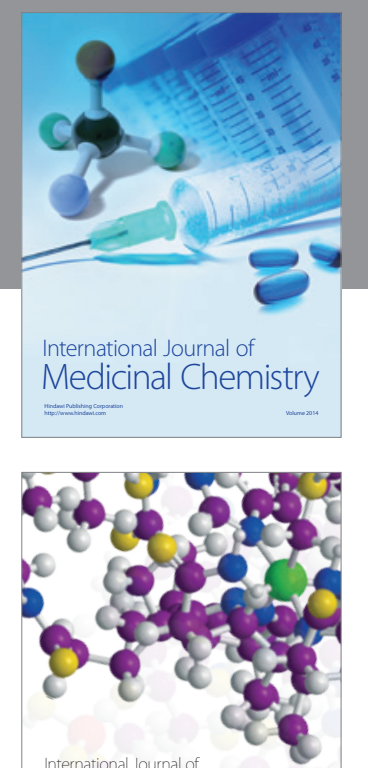

\section{Carbohydrate} Chemistry

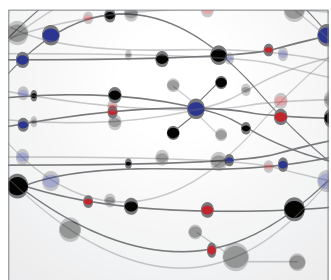

The Scientific World Journal
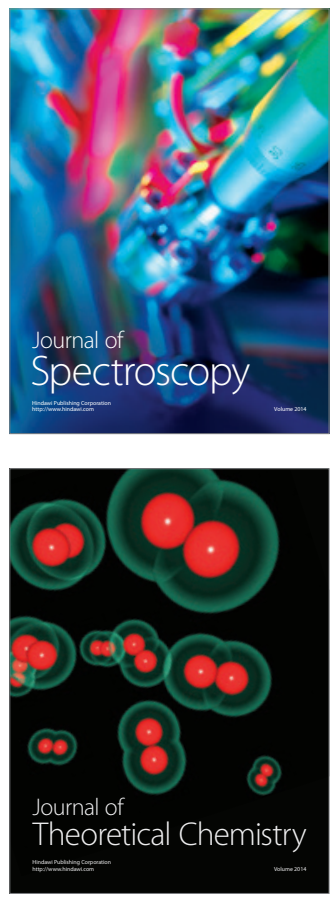
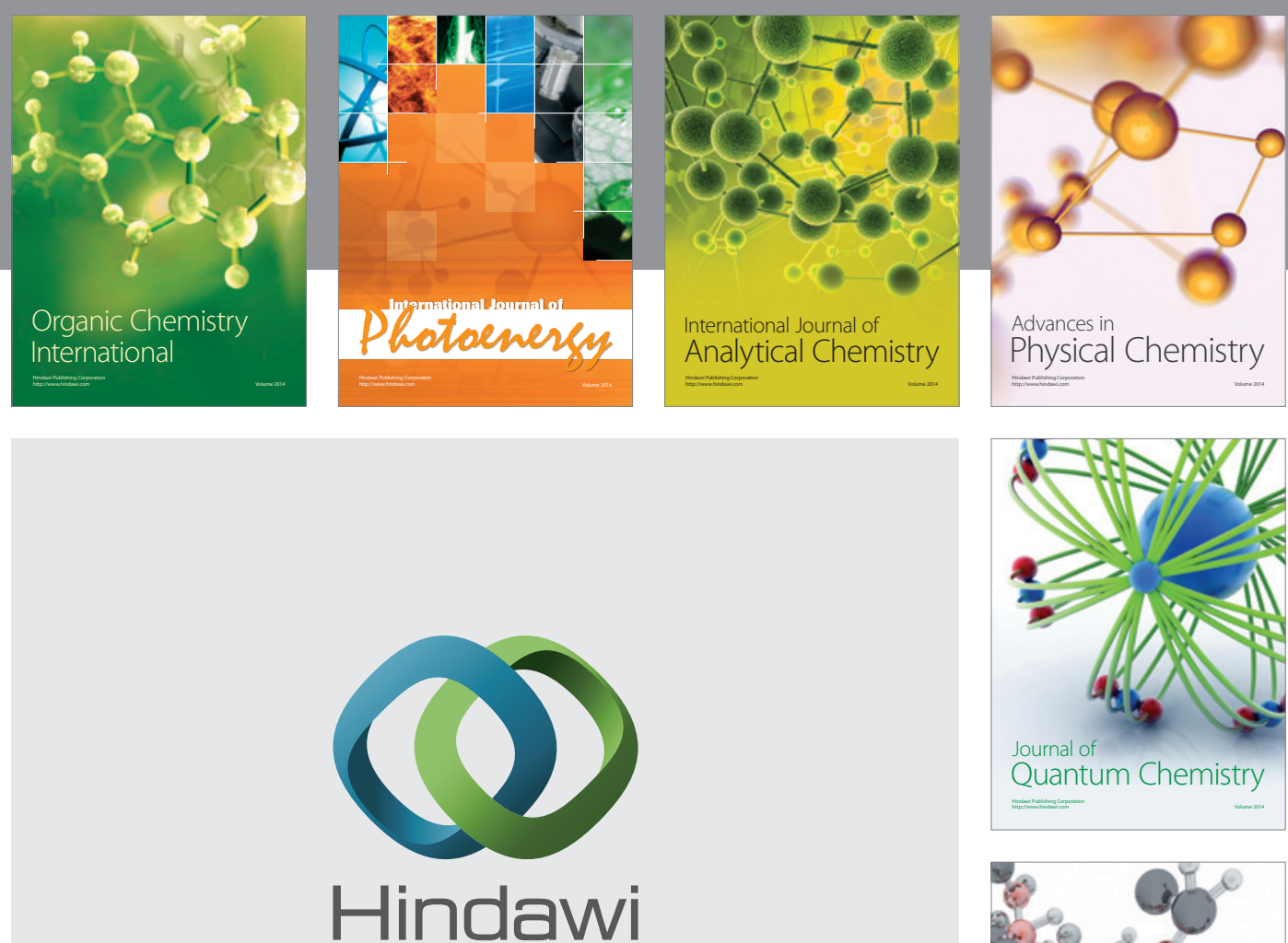

Submit your manuscripts at

http://www.hindawi.com

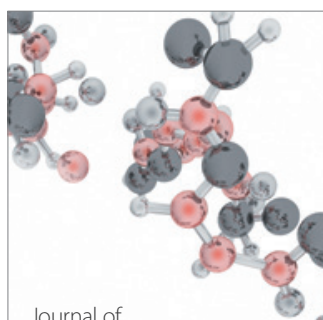

Analytical Methods

in Chemistry

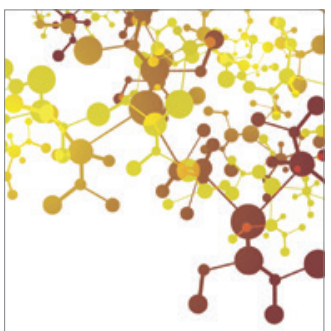

Journal of

Applied Chemistry

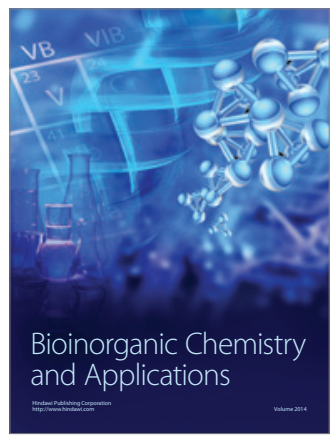

Inorganic Chemistry
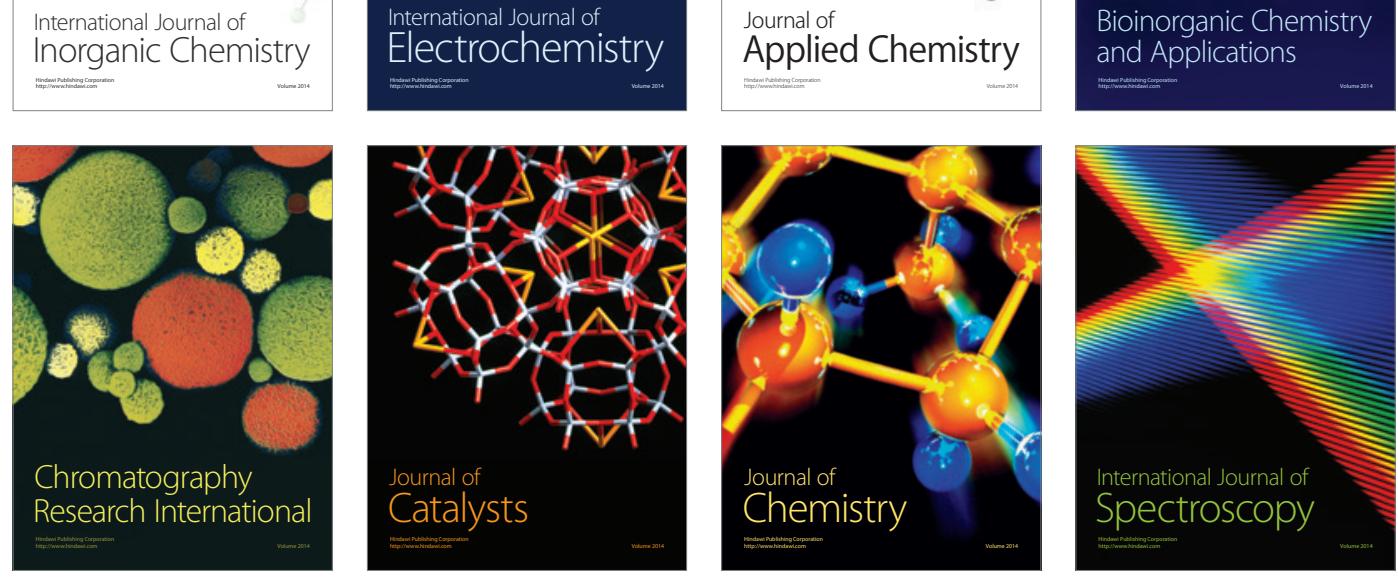